\title{
Case Study: Owens Sawmill: A Family Business Facing a Social Responsibility Dilemma ${ }^{1}$
}

By: Dianne H.B. Welsh and David Rawlings

Welsh, D.H.B., \& Rawlings, D. (2007). Owens sawmill: A family business facing a social responsibility dilemma. New England Journal of Entrepreneurship, 9(1), 1-2.

\section{***Note: Figures may be missing from this format of the document}

\begin{abstract}
:
This is a real case involving an SME that produces southern hardwood finished lumber. The family business faces a social responsibility dilemma in terms of displaced workers and limited job opportunities in the surrounding labor market if they purchase a new saw that would modernize production, improve profitability, and eliminate 50 percent of their labor costs. The most logical employment for these workers would be a cutter, loader, or hauler of logs, which have been determined to be some of the most dangerous jobs in the United States. This case requires students to examine the decision-making process of a modest family business in small, cohesive community and the ramifications of these decisions, as well as issues concerning technology and production improvements, displaced workers, social responsibilities, and the rights and responsibilities of employers and employees.
\end{abstract}

\section{Article:}

A small, family-owned sawmill is seeking to improve profitability. Scott and Beth Owens have the opportunity to purchase a new saw that is capable of cutting the same amount of wood in one shift as the current saw can cut in two shifts. Additionally, as employees become more proficient with its use, productivity will drastically improve. The couple must quickly decide whether to purchase a new saw or continue using the old saw because they have a short window of opportunity to sell the old saw, which will bring additional revenue. Normally, this type of saw is difficult to sell. Capital investments are difficult to recoup in this industry because the investment costs must be spread out over far fewer units of production than other types of sawmills ("Economic Choice" 2003).

If the new saw is bought, it allows Owens Sawmill to reach or exceed its usual two-shift production in only one shift. Therefore, the second shift will be eliminated. The most likely opportunities for those who work on the second shift will be out in the field as a cutter, loader, and hauler of logs. This job has been determined by safety officials to be the most dangerous job in the United States. The fatality rate for this position is the highest of any position-26 times greater than the national average (Christie 2003). While the Owens' are legally obligated to provide a safe environment for their employees, do they have a social responsibility?

\section{Personal Background}

Owens Sawmill was founded and is currently owned by Scott Owens and his wife, Beth of Arlington, Kentucky. Both are very involved in the day-to-day operations and share making decisions. The two form the upper management of Owens Sawmill.

Scott was born in Spokane, Washington, where his mother raised the family while his father, Tom, worked in Alaska. Scott played on his high school basketball team and graduated in 1980, at the age of 17. After graduation, he joined his dad in Ketchikan, Alaska. His father was on one of the first teams that went into the Alaskan wilderness to initiate construction of the road system. Scott's job was to drill and blast rock to clear land 
for road construction. His job was seasonal, so he returned to Washington State when operations shutdown during the winter months where he attended community college for one quarter and decided it was not for him.

By 1982, his father had moved to Kentucky and Scott joined him to operate a farm. He soon met his future wife, Beth, in the same town. Beth was the only girl in a family with three boys. Beth's family owns a horse farm that specializes in quarter horses. She attended community college and completed an associate's degree while working part time at a local hospital and volunteering at Hospice. Scott soon realized that agricultural employment did not pay well, so he returned to Alaska in 1983 to work on road construction. When he returned to Kentucky that winter, he had saved enough money to build a home for him and his wife. In 1988, Scott's father started logging so Scott bought a truck and a loader and was cutting, loading, and hauling the logs to the mills with his dad. Scott soon realized that there was more profit to be made by cutting the logs into lumber himself rather than just delivering the logs to another lumber mill. Owens Sawmill was born.

Scott and Beth received a government loan in 1989 for $\$ 30,000$ at 5 percent interest with the requirement that he hire four employees. They also borrowed \$30,000 from a local bank and purchased a mill and land in Arlington, Kentucky, where they erected a building from which the business still operates. Scott ran the daily logging operations, while Beth performed the bookkeeping and administrative functions. After six months, they realized that not enough lumber was being cut to pay their expenses. Therefore, a second shift was implemented and four additional employees were hired so they could double production without increasing their fixed costs, such as insurance and loan payments. As production increased, the company paid off its loans and became profitable. In 1992, they formed an S Corp. for tax purposes and to reduce their personal liability.

The Owens' expanded their operation over time by purchasing large tracts of forest land. Scott deploys his cutting crew to the tracts of land where there is demand for a specific type of wood. His crew cuts, loads, and transports the logs to the mill. Most of the same employees also work in the sawmill producing the finished lumber, which is then sold. The average tenure of the Owens Sawmill employees is 10 years, ranging from 5 to 17 years. The Owens' are contemplating starting a family and they would like to hire at least part-time help to assist Beth with the bookkeeping and office management duties. Beth enjoys her interaction with the employees and their families and considers this part of her life's purpose. Scott is 43 years old and Beth is 35 years old. Their current savings total around $\$ 50,000$ and they have under $\$ 5,000$ in their retirement accounts.

\section{Industry Background}

The National Hardwood Lumber Association releases a weekly Hardwood Market Report that separates hardwood lumber into three price categories: Northern Hardwoods, Southern Hardwoods, and Appalachian Hardwoods. The Kentucky area has Southern Hardwood. A 12-foot red oak log with a small end circumference of 24 inches will yield a total of 300 feet of usable lumber. A sawmill will purchase this log for about $\$ 0.70$ per foot, making the log worth about $\$ 210$. From this $\$ 210$, the money is split evenly between the landowner and the logger. This same 300-foot log will result in about 420 feet of lumber due to the scaling methods used. The lumber will then be separated into grades that determine the prices paid for the lumber.

The new technologically advanced saw is estimated to increase productivity by 25 percent, resulting in approximately $\$ 30,000$ more profit per year. The core of the employee base would remain intact if the technologically advanced saw was purchased. The job loss will be minimal; ranging from four to six displaced employees. The highest performing employees with the best accident records and the longest tenure would be retained. The laidoff employees may be offered employment in the future if Owens Sawmill keeps to its strategic long-term expansion plan. 


\section{Endnote}

1. The teaching note for this case study is available upon request to Dianne Welsh at dwelsh@ut.edu.

\section{References}

Christie, L. 2003.America's most dangerous jobs: The top 10 most dangerous jobs in America. [online].

October 13. (http://www. money.cnn.com/2003/10/13/pf/dangerousjobs/index.html).

Economic choice for hardwood sawmill operations. 2001. [online].

September 28. (http://www.cfr.msstate.edu/fwrc/forestp/echo.html).

\section{About the Authors}

DIANNE H.B. WELSH (dwelsh@ut.edu.) is the James W. Walter Distinguished Chair of Entrepreneurship, Professor of Management, and director of the Florida Entrepreneur and Family Business Center at the Sykes College of Business at the University of Tampa. A recognized scholar in international entrepreneurship and franchising, Dr. Welsh is coeditor of the first comprehensive volumes on global franchising in emerging and industrialized markets. She is the author of more than 100 published manuscripts that have appeared in the Academy of Management Journal, Journal of International Business Studies, Entrepreneurship Theory \& Practice, Journal of Business Venturing, Journal of Small Business Management, and others.

DAVID RAWLINGS holds a B.B.A. with a major in management and a concentration in entrepreneurship from John Carroll University in suburban Cleveland, Ohio. He wrote the case during his senior year of undergraduate study based on a true dilemma his cousin was facing. 